\title{
Evaluation of the Effects of Mobile Phones on the Neural Tube Development of Chick Embryos
}

\section{Mobil Cep Telefonunun Tavuk Embriyosunda Nöral Tüp Gelişimi Üzerine Olan Etkilerinin Değerlendirilmesi}

\author{
Ahmet Sukru UMUR ${ }^{1}$, Can YALDIZ ${ }^{2}$, Adem BURSALI ${ }^{3}$, Nurcan UMUR ${ }^{4}$, Burcu KARA ${ }^{5}$, \\ Mustafa BARUTCUOGLU ${ }^{1}$, Seda VATANSEVER ${ }^{5}$, Deniz SELCUKI ${ }^{6}$, Mehmet SELCUKI $^{1}$ \\ ${ }^{1}$ Celal Bayar University, Faculty of Medicine, Department of Neurosurgery, Manisa, Turkey \\ ${ }^{2}$ Sakarya Training and Research Hospital, Department of Neurosurgery, Sakarya, Turkey \\ ${ }^{3}$ Atatürk Hospital, Department of Neurosurgery, Balkesir, Turkey \\ ${ }^{4}$ Celal Bayar University, Vocational School of Health Services, Manisa, Turkey \\ ${ }^{5}$ Celal Bayar University, Faculty of Medicine, Department of Histology and Embryology, Manisa, Turkey \\ ${ }^{6}$ Celal Bayar University, Faculty of Medicine, Department of Neurology, Manisa, Turkey
}

Corresponding Author: Can YALDIZ / E-mail: drcanyaldiz@yahoo.com

\begin{abstract}
AIM: The objective of this study is to examine the effects of radiation of mobile phones on developing neural tissue of chick embryos.

MATERIAL and METHODS: There were 4 study groups. All Groups were placed in equal distance, from the mobile phones. Serial sections were taken from each Group to study the neural tube segments.

RESULTS: The TUNEL results were statistically significant $(p<0.001)$ at 30 and 48 hours in the third Group. We found low Bcl-2 levels partly in Group 4 and increased activity in Group 3. Caspase-3 was negative in the 48 and 72 hours in the Control Group, had moderate activity in the third Group 3, weak activity in the 48 hour, and was negative in the 72 hour in other groups. Caspase-9 immunoreactivity was weak in Group 1,2 and 3 at 30 hours and was negative in Group 1 and 4 at 48 and 72 hours. Caspase- 9 activity in the third Group was weak in all three stages. CONCLUSION: Electromagnetic radiation emitted by mobile phones caused developmental delay in chick embryos in early period. This finding suggests that the use of mobile phones by pregnant women may pose risks.
\end{abstract}

KEYWORDS: Mobile phone, Electromagnetic field, Neural tube development, Chick embryo

ÖZ

AMAÇ: Mobil cep telefonunun tavuk embriyosunda nöral tüp gelişimi üzerine olan etkilerinin değerlendirilmesi amacıyla bu çalışma yapıldı. YÖNTEM ve GEREÇLER: Araştırma kapsamında 4 farklı deney grubu oluşturuldu. Tüm gruplarda mobil cep telefonu eşit mesafeye yerleştirildi. Çalışmadaki tüm gruplardan nöral tüp segmentine yönelik seri kesitler alındı.

BULGULAR: Grup 3'deki 30. ve 48. saatlerdeki TUNEL sonuçları diğer gruplara göre istatistiksel olarak anlamlı olarak gözlendi ( $P<0.001)$. Kısmen grup 4'de Bcl-2 seviyesi normale yaklaşırken, grup 3'de aktivite artışı devam etti. Kaspaz 3 immunoreaktivitesi kontrol grubunda 48. ve 72. saatlerde negatif iken, grup 3'de orta şiddette devam ettiği, diğer gruplarda ise 48. saattlerde zayıf ve 72. saatte negatif olduğu izlendi. Kaspaz 9 immunoreaktivtesi grup 1, 2 ve 3'de 30. saatte zayıf şiddette iken, grup 1 ve 4'de 48. ve 72. saatlerde de negatif idi. Grup 3 'de ise kaspaz 9 immunoreaktivitesi her üç dönemde de zayıf şiddette devam etti.

SONUÇ: Çalışma sonucunda biz mobil telefonun yaydığı elektromanyetik radyasyonun doza bağımlı olarak erken embriyojenik dönemde tavuk embriyolarında gelişme gecikmesi yaptığını tespit ettik. Çalışma erken embriyonik dönemde sonlandırıldığı için geç dönem sonuçları için yorum yapılamamaktadır. Geç dönem sonuçları için daha uzun süreli çalışmaya ihtiyaç vardır.

ANAHTAR SÖZCÜKLER: Mobil cep telefonu, Elektromanyetik alan, Nöral tüp gelişimi, Tavuk embriyosu

\section{INTRODUCTION}

Human exposure to radio frequency (RF) electromagnetic fields (EMF) of mobile phones has dramatically increased over the recent years. So, the potential risks of EMF for human health have become a growing concern for the society. The effects of exposure to electromagnetic fields have been extensively studied in vitro and in vivo on mammalian cells for carcinogenesis, genetic damage, cell transformation, and embryological development. RF-EMF radiation can induce molecular responses, leading to cell proliferation, cell death, and DNA damage, altering gene expression in different cell types as reported in previous studies using in vivo or in vitro experiments. Despite previous studies, there is still limited knowledge about the adverse effects of RF-EMF radiation on human health, or the biological responses to RF-EMF radiation exposure. 
Apoptosis, the process of programmed cell death, is considered a vital biological occurrence for organisms. Apoptosis is a form of cell suicide with crucial roles in a wide range of developmental and normal physiological functions in animal species, resulting in diseases when mishandled. Apoptosis has a fundamental role in normal tissue homeostasis during embryogenesis and throughout the development of multicellular organisms. Any defect in apoptosis pathways is likely to result in impaired human development. Dysregulated apoptosis can be the underlying cause of various pathologies. A set of cytological features including nuclear chromatin condensation, DNA internucleosomal fragmentation, and activated caspases characterize apoptosis.

The literature contains a limited number of studies addressing the interactions between RF-EMF and the apoptotic process. There are reports of in vitro studies on different cells, with dissimilar findings, indicating that cell sensitivity to EMF varies by the type of cell.

It is common knowledge that environmental factors are also effective in embryonic development processes as well as genetic and metabolic factors. It has not been possible to fully identify defect formation mechanisms. Chromosomeprogrammed proteins, receptors and various reactions at the molecular level play roles at the basis of this process (27). It was considered that cell phone use, a strong magnetic area and radio frequency emitter, is effective in mechanisms and reactions occurring in the embryonic life, but no evidence could be found (8). Neuronal and spinal development stages of chick embryo are closely similar to the development stages of human embryos. Literature studies showed no studies that were focused on the effects of mobile phones on the stages of embryonic development of the neural tube.

This study was designed to probe into the effects of mobile phone-induced EMFs on neural tube development of chick embryo.

\section{MATERIAL and METHODS}

\section{Study Design (Experimental Groups):}

200 white Leghorn type Specific Pathogen-Free (SPF) eggs were obtained from the Veterinarian Control and Research Institute, Bornova, Izmir, Turkey. The eggs were incubated at $37.0 \pm 0.02^{\circ} \mathrm{C}$ and $50-60 \%$ relative humidity for $30,48,72$ hours. In this study, SAR Value: $0.77 \mathrm{~W} / \mathrm{kg}$, were used. Mobile phones were left at a distance $<25 \mathrm{~cm}$ (Figure 1) to the eggs. 4 working Groups were formed (Figure 2).

Group 1 ( $n=50$ eggs): Eggs not exposed to mobile cells

Group 2 ( $n=50$ eggs): Eggs exposed to the standby mode of mobile phones

Group 3 ( $n=50$ eggs): Eggs exposed to the calling mode of mobile phones. Mobile phones were called for 10 seconds every 30 minutes.

Group 4 ( $n=50$ eggs): Eggs exposed to the talking mode of the mobile phones. Mobile phones were kept in conversation mode 10 minutes every 60 minutes.
The eggs in each experimental Group were opened at 30, 48 and 72 hours of developmental stages. The embryos collected were then examined under a light microscope (Figure 3). They were then fixed by immersion in a $4 \%(\mathrm{~V} / \mathrm{V})$ formalin solution for $24 \mathrm{~h}$, embedded in paraffin wax and cut into $5 \mu \mathrm{m}$ sections for immunohistological studies and TUNEL staining.

\section{Immunohistochemical Analysis}

Immunohistochemical staining was performed for formalinfixed, paraffin-embedded sections. Sections were dewaxed overnight at $60^{\circ} \mathrm{C}$ and then in xylene for 30 minutes. After ethanol dehydration, the sections were washed with distilled water. Then, to inhibit endogenous peroxidase activity, they were treated with $2 \%$ trypsin (ab970, Apcam, Cambridge, UK) for $15 \mathrm{~min}$ at $37^{\circ} \mathrm{C}$ and incubated in $3 \% \mathrm{H}_{2} \mathrm{O}_{2}$ solution for $15 \mathrm{~min}$. They were rewashed with PBS and incubated with primary antibodies against bcl-2 (sc-7382, Santa Cruz, USA), Caspase-3 (NB 6001235, Novus Biologicals Littleton, USA), Caspase-8 (NB 600576, Novus Biologicals Littleton, USA) Caspase-9 (C-4356, Sigma, USA) for $18 \mathrm{~h}$ at $+4^{\circ} \mathrm{C}$. After washing with PBS, the anti-rabbit and anti-mouse secondary antibody biotinylated IgG (sc-2004, sc-2005, Santa Cruz, USA) was used for $30 \mathrm{~min}$, followed by three PBS washes. The streptavidinperoxidase complex (Histostain Plus kit Zymed 87-9999; Zymed, San Francisco, CA) was added for 30 min and washed in PBS for 3 times. In order to visualize immunoreactivity, sections were stained with diaminobenzidine-containing DAB Substrate system (DAB, K007, DBS, Pleasanton, CA, USA), and then, in order to provide counterstaining, they were stained with Mayer's hematoxylin (72804E, Microm, Walldorf, Germany). They were mounted with mounting medium (01730 Surgipath, Cambridge, UK) and examined under a light microscope (Olympus BX-40, Tokyo, Japan). Negative controls received similar treatment for each of the antibodies, with negative labeling in all cases.

\section{Tunel Staining}

Paraffin sections were deparaffinized and rehydrated. Prepared as detailed above, deparaffinized and rehydrated sections were then stained with a commercial kit (Apoptag, S7165, Chemicon, Billerica, MA, USA) in compliance with the manufacturer's instructions. They were incubated for $30 \mathrm{~min}$ with $20 \mu \mathrm{g} / \mathrm{mL}$ proteinase $\mathrm{K}$ and rinsed again three times in PBS for $5 \mathrm{~min}$. They were then incubated in TdT-enzyme solution at $37^{\circ} \mathrm{C}$ for $1 \mathrm{~h}$. Next, the sections were rinsed three times with stop/wash buffer (supplied by Chemicon) at room temperature for 15 min each. After that, sections were incubated with anti-digoxigenin conjugate (supplied ready to use by Chemicon) for $30 \mathrm{~min}$. Then, they were washed with PBS for 10 min and mounted with mounting medium (Scytek Laboratories, Logan, UT, USA). For negative staining control, $\mathrm{TdT}$ was excluded during the remaining reactions.

\section{Evaluation of Sections}

All sections were studied under a light microscope (Olympus BX40, Tokyo, Japan). The intensity of labeling was semiquantitatively and independently graded by two blind 


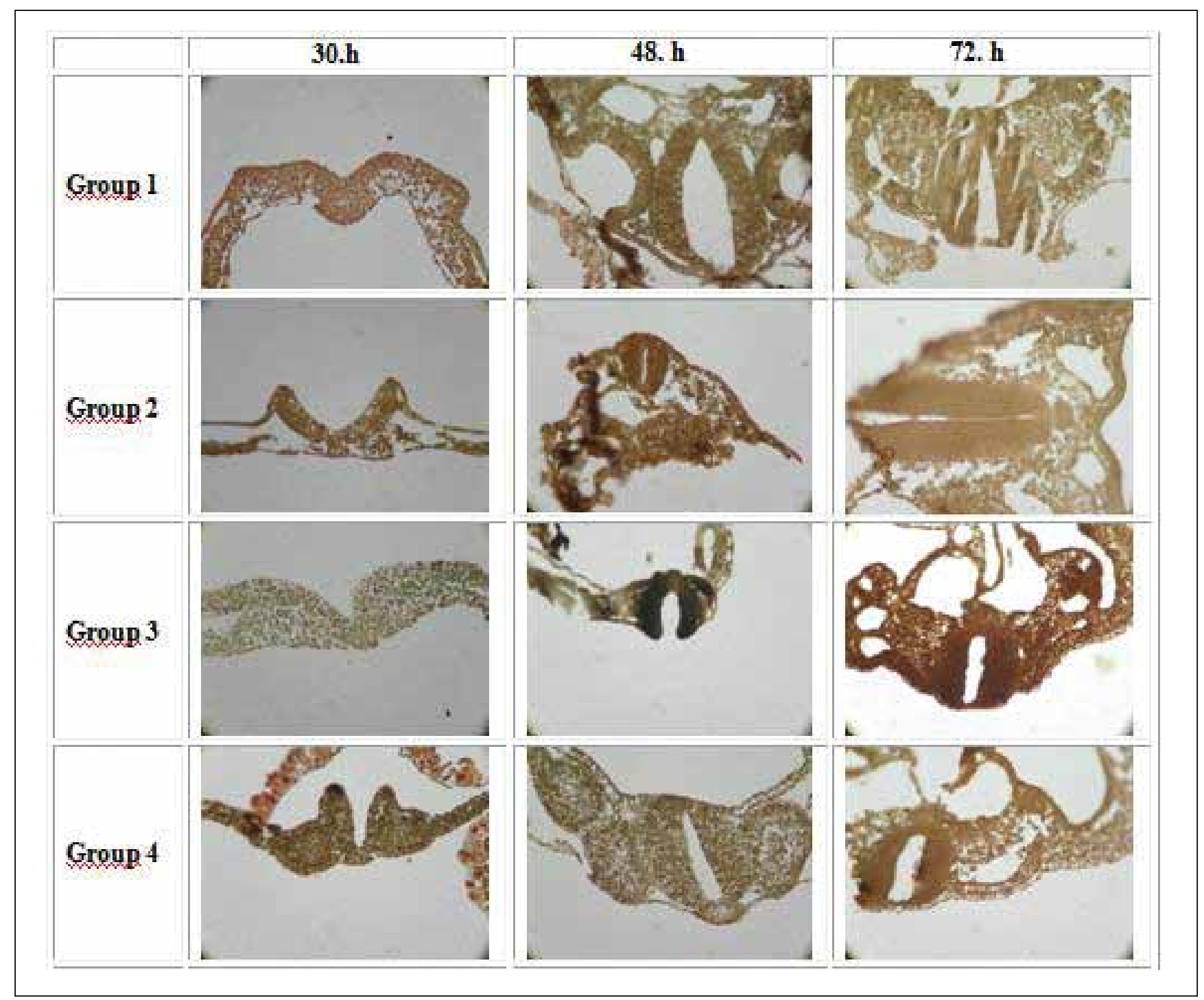

Figure 1: Examples of TUNEL staining in the groups (x400).
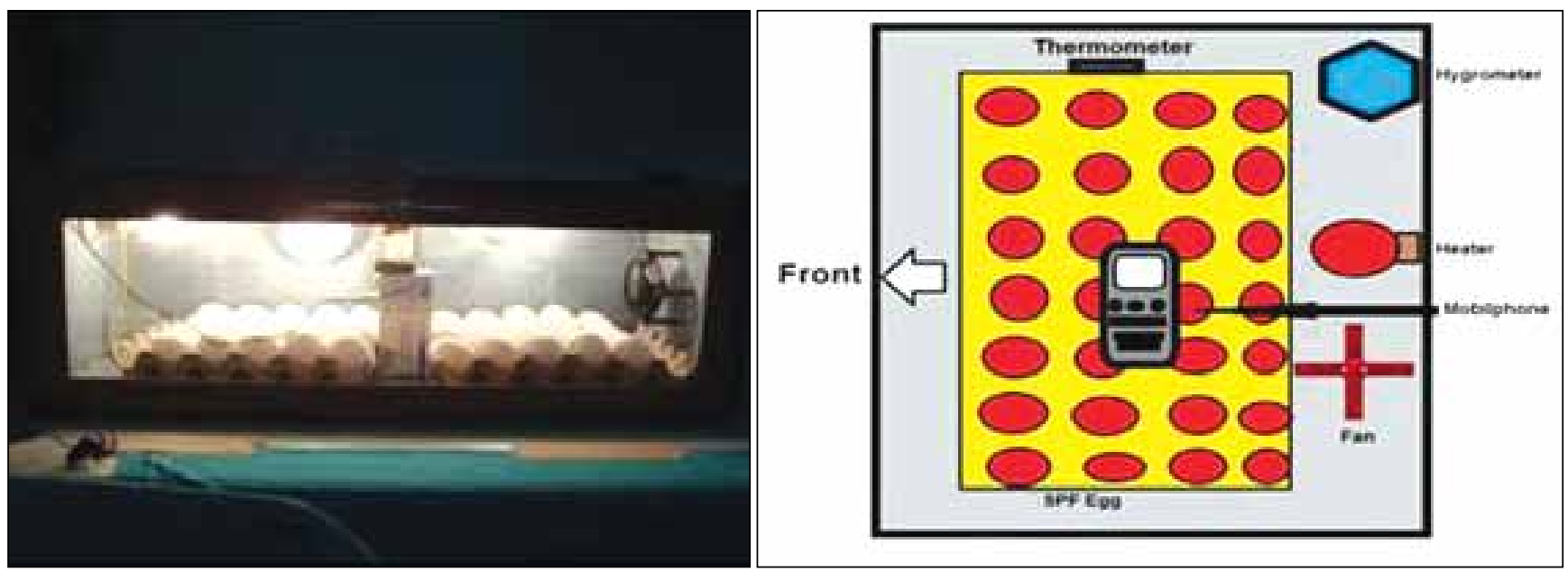

Figure 2: Photographic and schematic design of the incubator. 


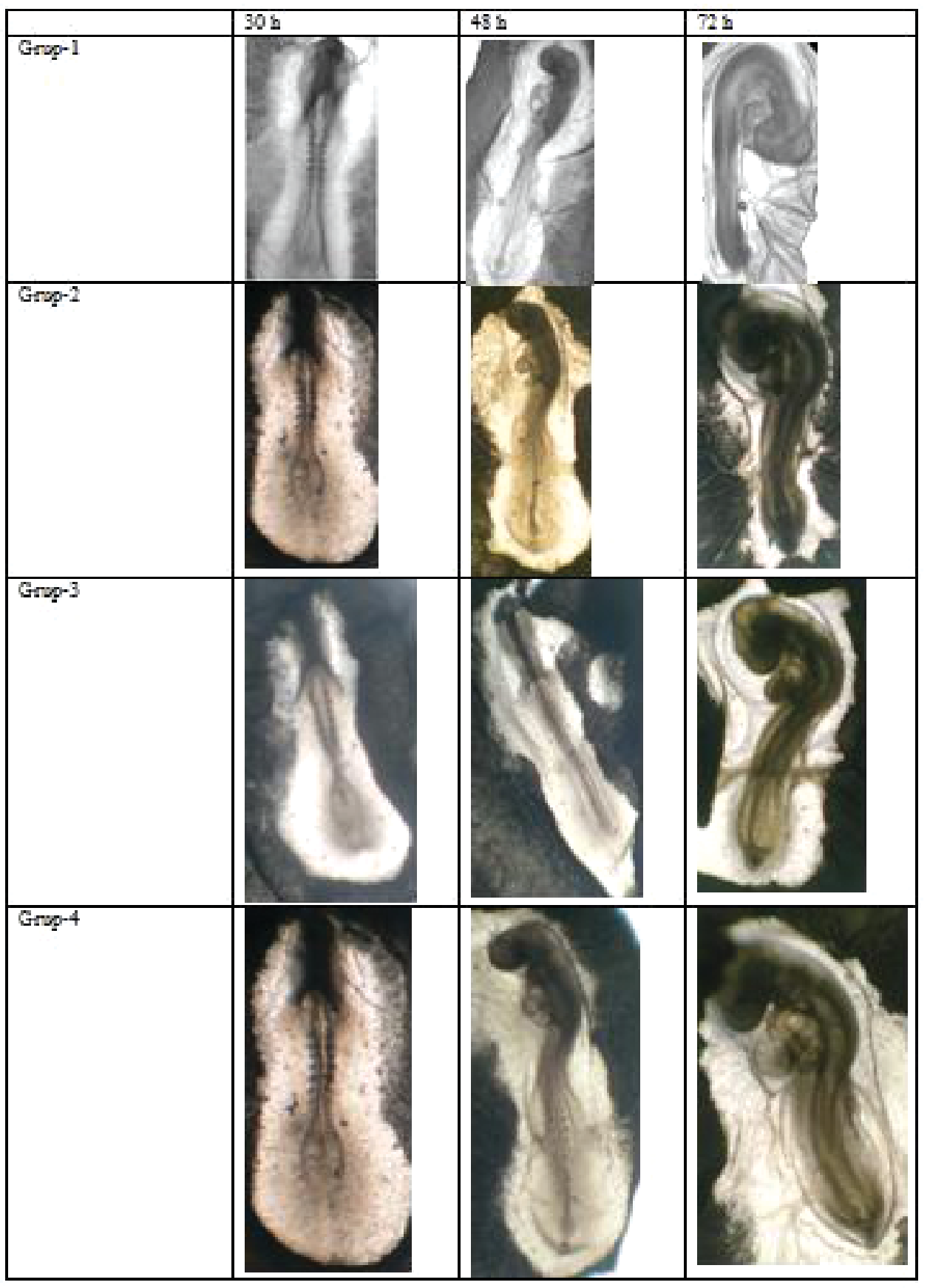

Figure 3: Dissection microscopic images (x15). observers based on the following scale: weak $(+)$, moderate $(++)$, and strong $(+++)$ labeling (Table I).

The mean number of apoptotic cells (labeled brown) was calculated by counting TUNEL-positive cells in randomlychosen fields per case. In each case, the total number of TUNEL-positive and negative cells was counted and TUNELpositive cells were given as a percentage of the total number. Cells in areas with necrosis, poor morphology, or at section margins were not included in the counting.

\section{Statistical Analysis}

SPSS 10.0 for Windows (SPSS, Chicago, IL, USA) was used for statistical comparison of the data. Data are expressed as mean \pm SEM. All inter-group differences were statistically analyzed using one-way ANOVA, where appropriate. $p$-value $<0.05$ was considered to be statistically significant (Table II).

\section{RESULTS}

\section{Apoptotic Evaluation with the TUNEL Technique}

In the $30^{\text {th }}$ hour of the embryos, open neural tubes were seen in the tail sections of all Groups, and TUNEL-positive 
Table I: Immunolabelling Intensity in Sections According to Groups

\begin{tabular}{|c|c|c|c|c|c|}
\hline & & Group 1 & Group 2 & Group 3 & Group 4 \\
\hline \multirow{3}{*}{$\mathrm{Bcl}-2$} & $30 . h$ & - & - & - & - \\
\hline & 48.h & - & - & - & - \\
\hline & 72.h & - & - & - & - \\
\hline \multirow{3}{*}{ Kaspaz-3 } & 30.h & + & + & ++ & + \\
\hline & 48.h & - & + & $+/++$ & $-/+$ \\
\hline & 72.h & - & - & ++ & - \\
\hline \multirow{3}{*}{ Kaspaz-8 } & $30 . h$ & - & + & ++ & + \\
\hline & 48.h & - & - & ++ & - \\
\hline & 72.h & - & - & & - \\
\hline \multirow{3}{*}{ Kaspaz-9 } & $30 . h$ & + & + & - & + \\
\hline & 48.h & - & - & - & - \\
\hline & 72.h & - & ++ & - & - \\
\hline
\end{tabular}

Table II: Immunolabelling Intensity in Sections According to Groups

\begin{tabular}{|c|c|c|c|}
\hline & $30 . h^{a}$ & 48. $h^{b}$ & 72. $h^{G}$ \\
\hline Group 1 & $\% 2.2 \pm 0.25$ & 0 & 0 \\
\hline Group 2 & $\% 2.6 \pm 0.30$ & 0 & 0 \\
\hline Group 3 & $\% 4 \pm 0.33$ & $\% 2.3 \pm 0.30$ & 0 \\
\hline Group 4 & $\% 3.1 \pm 0.37$ & 0 & 0 \\
\hline
\end{tabular}

Statistical analysis of the differences between the experimental groups

a(G1-G2: $p>0.05, G 1-G 3:{ }^{* * *} p<0.001$, G1-G4: $\left.{ }^{* *} p<0.01, G 2-G 3:{ }^{* * *} p<0.001, G 2-G 4: p<0.05, G 3-G 4: p<0.05\right)$.

b(G1-G2: $\left.p>0.05, G 1-G 3:{ }^{* * *} p<0.001, G 1-G 4: p>0.05, G 2-G 3:{ }^{* * *} p<0.001, G 2-G 4: p>0.05, G 3-G 4:{ }^{* * *} p<0.001\right)$.

G(G1-G2: $p>0.05, G 1-G 3: p>0.05, G 1-G 4: p>0.05, G 2-G 3: p>0.05, G 2-G 4: p>0.05, G 3-G 4: p>0.05)$.

*Statistically significant.

cells were observed in the upper region of the open neural tubes, but an increased number of apoptotic cells were detected particularly in Group $3(4 \% \pm 0.33)$, followed in order by Group $4(3.1 \% \pm 0.37)$, Group $2(2.6 \% \pm 0.30)$ and Group $1(2.2 \% \pm 0.25)$. The percentage of apoptotic cells in Group 3 was significantly higher when statistically compared with Group 1 and $2(P<0.001)$, except for Group $4(P>0.05)$. The percentage of apoptotic cells in Group 1 was insignificant when statistically compared with Group 2 and 4 ( $>>0.05)$.

In the $48^{\text {th }}$ hour of the embryos, the neural tube was completely closed in sections of Group 1, 2 and 4, and the TUNEL-positive cells were not observed. However, tail sections of Group 3 showed open neural tube, and TUNEL-positive cells were observed in the upper region open neural tube. The percentage of apoptotic cells in Group 3 was significantly higher when statistically compared with other Groups $(P<0.001)$. However, Group 1, 2, 4 were not significantly different $(P>0.05)$ when compared with each other.

In the $72^{\text {nd }}$ hour of the embryos, closed neural tubes were observed in the sections of all Groups, and the Tunel-positive cells were not seen. Apoptotic activity results and staining examples of the Groups are seen in Table II, Figure 1.

\section{Immunohistochemical Evaluation}

$\mathrm{BCl}-2$ : As a result of the examination in the $30^{\text {th }}$ hour, while the $\mathrm{Bcl}-2$ immunoreactivity was moderately positive in Group 1 (Control) and Group 2 (Standby), it was observed to be mildly positive in Group 3 and Group 4. Since Bcl-2 is a factor secreted for the protection of cells at the stage of closing of neural tubes where TUNEL positive cells were observed, $\mathrm{Bcl}-2$ was secreted for the protection of neural tube cells during this period. While $\mathrm{Bcl}-2$ immunoreactivity was weak in examples in the Group 1 and 2 in the $48^{\text {th }}$ hour, it was observed to be moderate in the $30^{\text {th }}$ and $48^{\text {th }}$ hours. During this period, particularly in Group 3 (call), since the neural tube was open, secretion of $\mathrm{BCl}-2$ suggested that it was triggered for protection from apoptosis. And in the $72^{\text {nd }}$ hour, while the $\mathrm{Bcl}-2$ immunoreactivity was moderate in Group 1 and 3, it was observed to be mild in Group 1 and 4. While during the early period the Bcl-2 immunoreactivity in Group 1 and Group 2 was similar, increased $\mathrm{Bcl}-2$ immunoreactivity in Group 3 and 4 suggested that this was triggered by mobile phones (Figure 4).

Caspase-3: While immunoreactivity was observed to be moderate in Group 3, it was mild in other Groups. While 


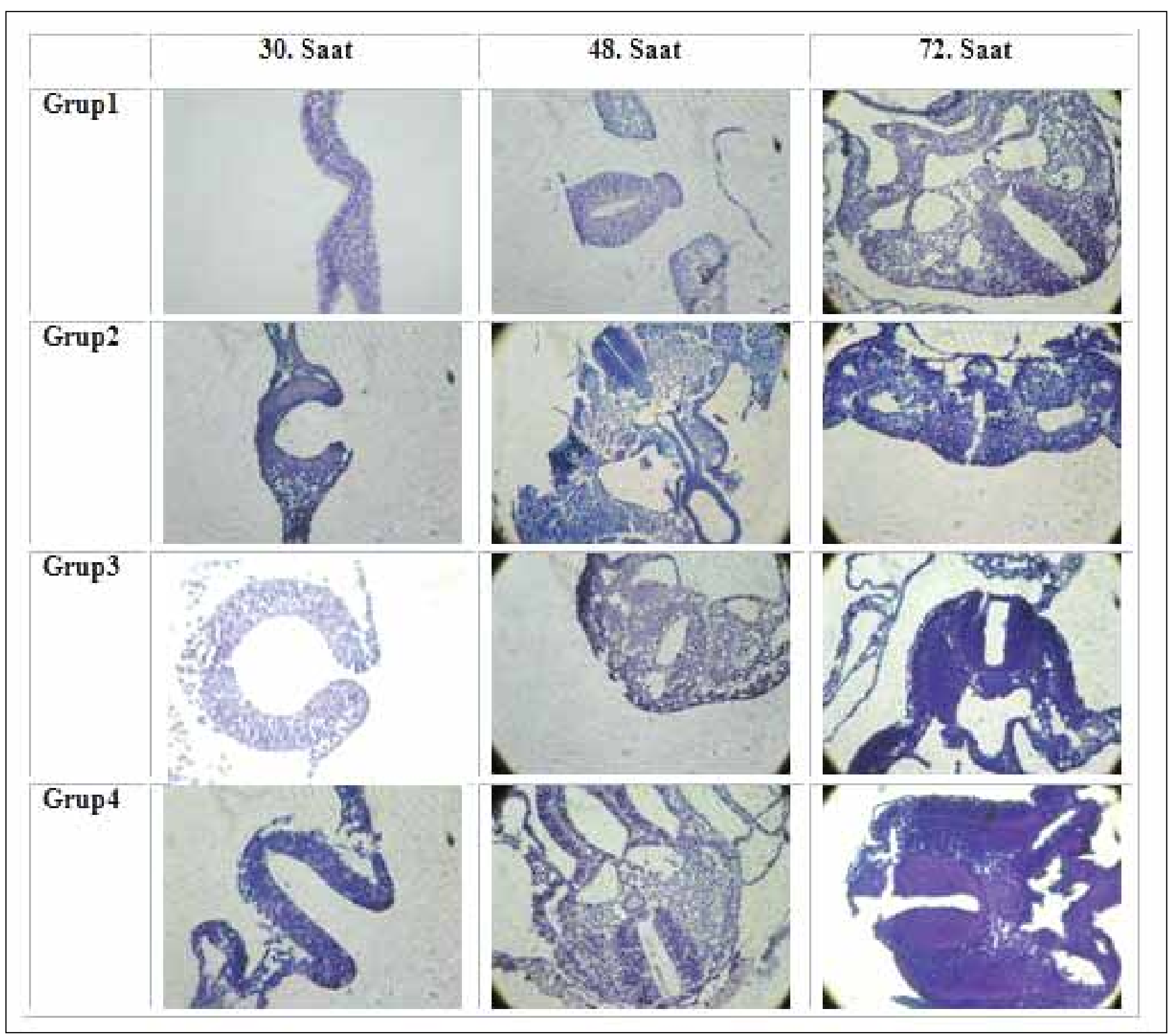

Figure 4: $\mathrm{Bcl}-2$ immunoreactivity in groups (x200).

Caspase-3 immunoreactivity was negative in the Control Group in the $48^{\text {th }}$ and $72^{\text {nd }}$ hours, it was observed to be moderately present in Group 3, and mild in $48^{\text {th }}$ hours and negative in $72^{\text {nd }}$ hours in other Groups. Higher observation of apoptotic cells in Group 3, the TUNEL results, and the continuity of Caspase-3 show that the apoptosis has been triggered (Figure 5).

Caspase-8: While Caspase-8 immunoreactivity was negative in the Control Group in all three periods, it was mildly positive in the $30^{\text {th }}$ hour in Group 2 and 4, and negative in the $48^{\text {th }}$ and $72^{\text {nd }}$ hours. And in Group 3, Caspase-8 immunoreactivity was observed to be moderately positive in all three periods. This suggests that with Caspase-3 immunoreactivity, Caspase-8's positivity is triggered intrinsically $b$ apoptotic mechanisms in Group 3 (Figure 6).
Caspase-9: While Caspase-9 immunoreactivity was mild in Group 1, 2 and 3 in the $30^{\text {th }}$ hour, it was negative in Group 1 and 4 in the $48^{\text {th }}$ and $72^{\text {nd }}$ hours. While Caspase-9 immunoreactivity was negative in Group 2 in the $48^{\text {th }}$ hour, it was found to be mildly positive in the $72^{\text {nd }}$ hour. In Group 3, it was found that Caspase- 9 immunoreactivity continued mildly in all three periods (Figure 7).

Immunoreactivity densities of all periods and Groups are summarized in Table I.

In line with these results, we conclude that the molecules in charge of the apoptotic mechanism during the closing of the neural tube could be responsible for the positivity of Caspase- 3 and 8 in addition to neural tube opening and the TUNEL positive cell presence observed particularly in Group 3 in the $48^{\text {th }}$ hour. 


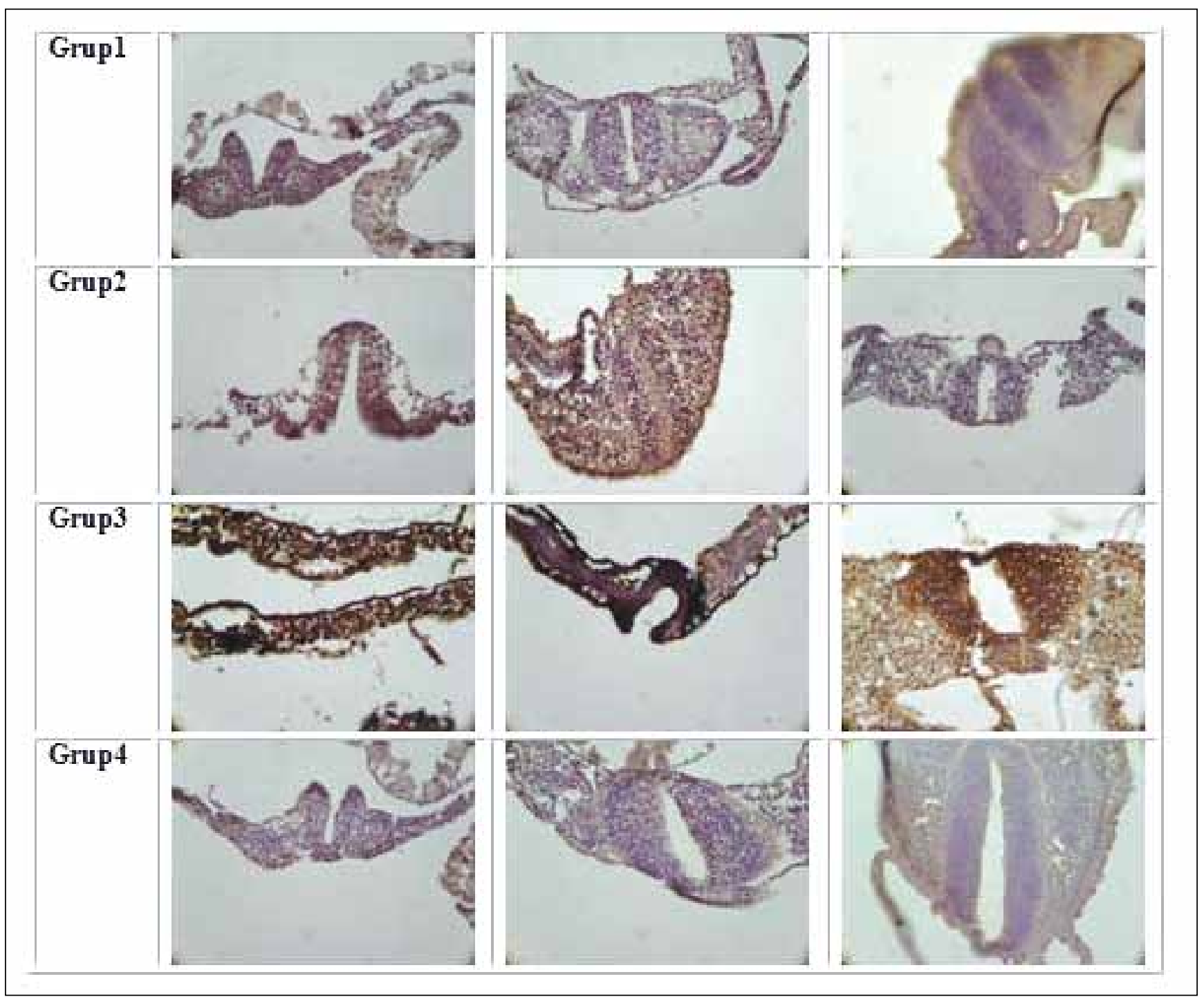

Figure 5: Caspase-3 immunoreactivity in groups (x200).

\section{DISCUSSION}

Non-ionizing radiation, the radiation emitted by radio frequency waves, is completely different from $X$ and gamma rays. It causes no ionization in human body. The potential of all systems known to be emitting non-ionizing radiation, and particularly the mobile phones and base stations that have been developed and become widespread since the early 1990's to pose various risks for the human health has been at the root of many discussions and still ongoing researches in the scientific world $(12,22)$.

Mobile phones are devices that transmit low-power radio frequency signals. When we talk on mobile phones, our voice, our short text message or images are translated into radio signals. The mobile phones that are being used today operate in the 800-1900 Mhz range (1).

Mobile phones and base stations emit light rays in different forms. Mobile phones emit radiation in certain intervals during the phone conversation and in standby mode. And base stations emit radiation continually. The radiation in mobile phones peaks while establishing connection, and is reduced after a connection is established (24).

Tissues and cells heated as a result of exposure to RF and the physiological response created in the body in return may result in certain harmless or harmful changes (34). Temperature increase in the entire body may affect particularly the babies, children and the elderly. The lens of the eye, the testis and the nervous system, which have more limited capacity to diffuse heat, are more prone to local influences (1).

Today, the number of mobile phone users in Turkey has reached a majority of the population. Although there are many studies suggesting that emissions below international safety limits have no impact on human health, no powerful, reliable and consistent studies can argue that there are no such risks $(5,13,28)$. 
There are three important phases in the development of the central nervous system. These are the neurulation, neural tube in the tail bud and dedifferentiation stages. In the neurulation phase during the early third week, the formation of the three primary germ cell layers (ectoderm, mesoderm and endoderm) and the notochord have been completed. Then starts the differentiation of tissues and organs $(4,15,31)$. The nervous system, which is first formed in the embryological development and is the last system where development has been completed, forms from the ectoderm layer. $(20,24,27,30)$.

Apoptosis is a genetically programmed cell-death process ensuring the safe removal of aged, worn out, overproduced, irregularly developed or genetically damaged cells $(14,26)$. Different environmental stimuli may trigger apoptosis in different types of cells. In almost all cells, apoptosis may trigger ionizing radiation, inflammatory cytokines, immunoregulatory cytokines, oxidative stress, changes in the redox potential, disappearance of growth factors or trophic factors, and mechanical stress $(2,29,32)$.

The literature contains many studies conducted about the impacts of electromagnetic waves emitted by mobile phones so far on human health $(5,8,13,28)$.

In a record-based study conducted by Auvinein et al. on 2588 persons living in Finland, the effects of mobile phone use on the incidence of brain tumors and salivary gland cancer have been investigated. This study included only the users of analog mobile phones. The study showed an increase in glioma incidence linked with mobile phone use (3).

In another record-based case-control study by Hardell et al., the previous study was supplemented by a questionnaire section about wireless telephones; the study also included those who had antennas in their car phones and those with manually operated phones. In this study, where the records were collected from regional centers of oncology and which is conducted on 2899 subjects, it was found that acoustic neuroma had the highest incidence in analog phone users. In this study, where the duration of telephone use will be acceptable, it was shown that there was an increase in the risk of cancer with an increase in the duration of use and that there was a link between the site of the tumor and the location of the telephone during the telephone conversation $(3,11,21)$.

A hospital-based case-control study conducted on 176 subjects by Muscat et al. probed into the presence of a possible relationship between mobile telephone use and acoustic neuroma. It was suggested that there was an increase in the length of the duration of mobile phone use and risk of cancer (10).

A study about long-term mobile phone use and cancer reported in 2007 by Hardell et al. investigated the effects of mobile phone use for at least 10 years on cancer. This study scanned the studies previously published in Pub-Med (www.ncbi.nlm.nih.gov), and included 18 studies made on this subject matter. Studies conducted in the USA, Sweden, Denmark, Finland, United Kingdom, Germany and Japan and covering the period between 1997 and 2004 were scanned, and it has been concluded, as a result of detailed investigation, that mobile phone use for 10 years increased the risks of acoustic neuroma and glioma (17).

As such, a study conducted by Lönn et al on 752 subjects living in Sweden argued that mobile phone use for at least 10 years increased the risk of acoustic neuroma. The results obtained suggest that particularly long-term mobile phone use may have serious effects on cancer (25).

In another study, Dasdag S. et al. observed that the radiation emitted by mobile phones $(0.15 \mathrm{~W} / \mathrm{kg})$ has no effects on peripheral blood parameters. They found no changes in rectal temperatures, reporting low birth weight in pregnant rats (8).

Radio frequency waves emitted by mobile phones cause many harmful effects at the cellular and molecular levels. While Lai et al. report that exposure to radio frequency waves created DNA breaks in the brain cells of rats (16), and, in parallel with this finding, Robison et al. observed a decrease in DNA repair rates in $\mathrm{HL}-60$ and $\mathrm{HL}-60 \mathrm{R}$ cell lines with the effect of electromagnetic area (6). When human full blood samples are exposed to $7,7 \mathrm{GHz}$ frequency microwave radiation, a correlation was observed between the chromosomal errors created (acentric fragments and dysenteric chromosomes) and micronucleus incidence (9). In a study conducted by Maes et al. using human peripheral blood lymphocytes, it was argued that $2450 \mathrm{MHz}$ radio frequency waves caused a marked increase in the formation of micronuclei and in the incidence of chromosomal errors (19). All such negative effects of magnetic areas on the DNA bring into mind that it may have cancerogenic and teratogenic effects. To this end, it was stated that mobile phone use created oxidative stress and could thus increase the risk of cancer (18). Lary et al. demonstrated that $27.12 \mathrm{MHz}$ radio frequency waves had teratogenic effects in rats (19).

In this present study, we created four groups: control, stand by, call, and talk. In the $30^{\text {th }}, 48^{\text {th }}$ and $72^{\text {nd }}$ hours, histological examinations were made in consideration of Tunel, $\mathrm{Bcl}-2$, and Caspase-3,8, 9. An evaluation of TUNEL results showed that the neural tube opening observed in the $30^{\text {th }}$ hour continued in Group 3 samples in the $48^{\text {th }}$ hour too, but during the progressive phase of embryonic development (in the $72^{\text {nd }}$ hour), the neural tube was observed to be closed. TUNEL results in the $30^{\text {th }}$ and $48^{\text {th }}$ hours in Group 3 was found statistically more meaningful $(P<0.001)$ than other groups. It was also found that neural tube being open in the Group where there were only full-time no-answer calls made by mobile phones, that is only full-time no-answer calls rather than talking on the phone, caused delays in the closing of the neural tube.

In parallel with these results, in addition to the presence of the neural tube opening and TUNEL positive cells observed particularly in Group 3 in the $48^{\text {th }}$ hour, it was also concluded that positive Caspase- 3 and 8 and the electromagnetic waves emitted by mobile phones affected the molecules responsible 
for the apoptotic mechanism during the closing of the neural tube neural tube, and could cause delays in the closing process. The closing delay and the apoptotic process being more noticeable in Group 3 compared with other groups was linked with full-time no-answer calls which caused mobile phones to emit more electromagnetic radiation waves. There were no other studies comparable to our study in the literature. However, the literature contains many studies conducted on the effects of mobile phones on embryonic life $(6,7,8,31,33)$.

\section{CONCLUSIONS and SUGGESTIONS}

There are many issues yet to be revealed related to the effects of the electromagnetic radiation emitted by mobile phones and base stations on human health.
Different results were obtained on the effects of such radiation on human health in laboratory tests conducted so far, in studies conducted using laboratory animals, and in epidemiological studies. We, in this study, found that the electromagnetic radiation emitted by mobile phones resulted in developmental delays in chick embryos depending on the dosage during the early embryogenic period, and could cause malformations. This finding proves that mobile phone use by pregnant women could pose some potential risks.

It is not likely for us to completely remove electromagnetic radiation from our lives. So, just as in every new technology, it would be very wise to be careful when using them, observe their potential damages, and minimize such damages with the help of science and technology.

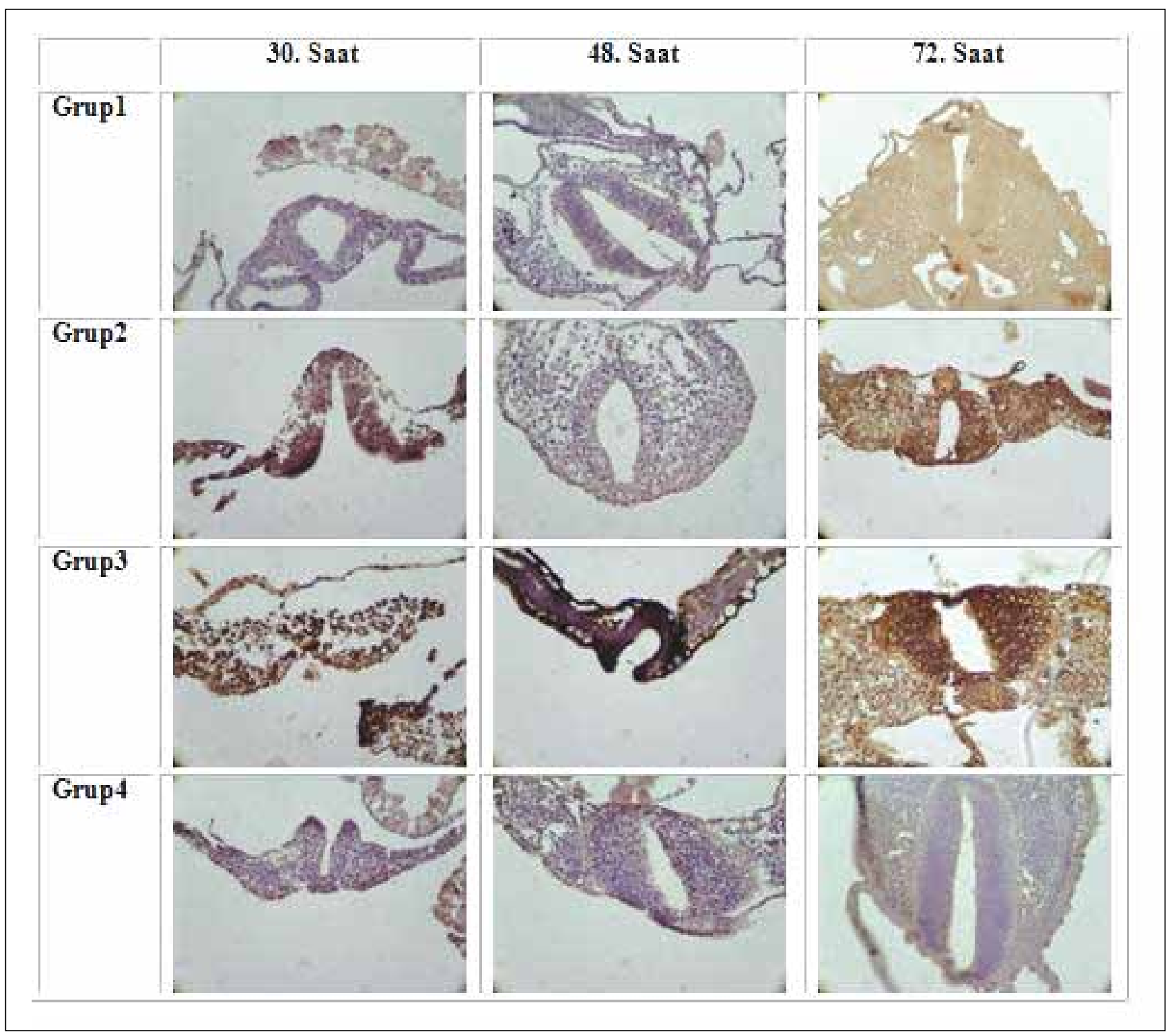

Figure 6: Caspase-8 immunoreactivity in groups (x200). 


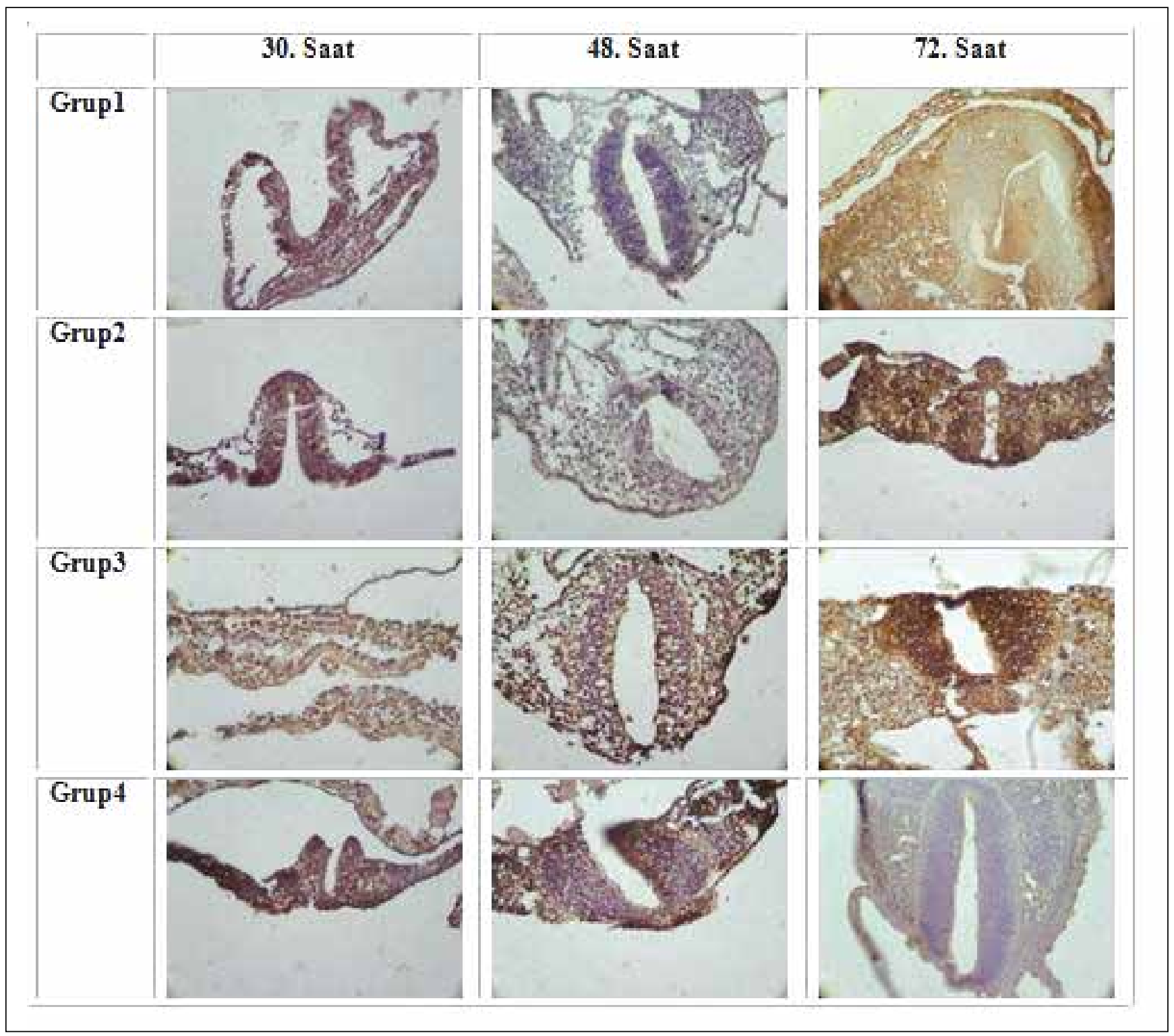

Figure 7: Caspase-9 immunoreactivity in groups (x200).

\section{REFERENCES}

1. Ahlbom A, Gren A, Kheifets L, Savitz D, Swerdlow A: epidemiology of health effects of radiofrequency exposure. Environ Health Perspect 112 (17):1741-1754,2004

2. Alles A, Alley K, Barrett JC, Buttyan R, Columbano A, Cope FO, Copelan EA, Duke RC, Farel PB, Gershenson LE: Apoptosis: A general comment. FASEB J 5: 2127-2128,1991

3. Auvinen A, Hietanen M, Luukkonen R, Koskela RS: Brain tumors and salivary gland cancers among cellular telephone users: Epidemiology 13:356-359,2002

4. Colas JF, Schoenwolf GC: Towards a cellular and molecular understanding of neurulation. Developmental Dynamics 221: 117-145, 2001
5. Chia SE, Chia HP, Tan JS: Prevalence of headache among handheld cellular telephone users in Singapore: A community study. Environ Health Perspect 108:1059-1062, 2000

6. Conover DL, Foley ED, Hanser PL: Teratogenic effects of $27.12 \mathrm{MHz}$ radiofrequency radiation in rats. Teratology 26 : 299-309,1982

7. Dasdag S, Akdag MZ, Ulukaya E, Uzunlar AK, Ocak AR: Mobile phone exposure does not induce apoptosis on spermatogenesis in rats. Archives of Medical Research 39: 40-44,2008

8. Dasdag S, Akdag MZ, Ayyıldız O, Demirtas OC, Yayla M, Sert C: Do cellular phones alter blood parameters and birth weight of rats? Electro-and Magnetobiology 19 (1):107-113, 2000 
9. Garaj-Vrhovac V, Fucic A, Horvat D: The correlation between the frequency of micronuclei and specific chromosome aberrations in human lymphocytes exposed to microwave radiation in vitro. Mutation Res 281(3):181-186,1992

10. Hardell L, Carlberg M, Söderqvist F, Mild KH, Morgan LL: Longterm use of cellular phones and brain tumours: Increased risk associated with use for $>$ or $=10$ years. Occup Environ Med 64:626-632, 2007

11. Hardell L, Mild KH, Carlberg M: Case-control study on the use of cellular and cordless phones and the risk for malignant brain tumours. Int J Radiat Biol 78:931-936,2002

12. KnawB:Radiation, non-ionizing. Encyclopedia of occupational health and safety, vol:2, 4th ed, Geneva: ILO, 1998

13. Koivisto $M$, Haarala C, Krause CM: GSM phone signal does not produce subjective symptoms. Bioelectromagnetics 22: 212-215,2001

14. Kam PCA, Ferch NI: Apoptosis: Mechanisms and clinical implications. Anaesthesia 55:1081-1093,2000

15. Larsen WJ: Human embryology, 2nd ed, New York: Churchill Livingtone, 1997:19-106

16. Lai H, Singh NP: Melatonin and a spin-trapcompound block radiofrequency electromagneticradiation-induced DNA strand breaks in rat brain cells. Bioelectromagnetics 18 : 446-454,1997

17. Lönn S, Ahlbom A, Hall P, Feychting M: Mobilephone use and the risk of acoustic neuroma. Epidemiology 15:653-659,2004

18. Moustafa YM, Moustafa RM: Effects of acute exposure to the radiofrequency fields of cellular phones on plasma lipid peroxide and antioxidase activities in human erythrocytes. Journal of Pharmaceutical and Biomedical Analysis 26: 605-608, 2001

19. Maes A, Verschaeve L, Arroyo A, De Wagter C, Vercruyssen $\mathrm{L}$ : In vitro cytogenetic effects of $2450 \mathrm{MHz}$ waves on human peripheral blood lymphocytes. Bioelectromagnetics 14 : 495-501,1993

20. Monk CS, Webb SJ, Nelson CA: Prenatal neurobiological development, molecular mechanisms and anatomical change. Developmental Neurophycholgy 19: 211-236,2001

21. Muscat JE, Malkin MG, Shore RE, Thompson S, Neugut Al, Stellman SD, Bruce J: Handheldcellular telephones and risk of acoustic neuroma. Neurology 58:1304-1306,2002
22. Radyasyon ve Sağlık. Teknik Rapor No:1 Ankara: HASAK, Sağlık ve Sosyal Yardım Vakfı, 1994

23. Radon K, Spegel H, Meyer N, Klein J, Brix J, Wiedenhofer A, Eder H, Praml G, Schulze A, Ehrenstein V, Von Kries R, Nowak $\mathrm{D}$ : Personal dosimetry of exposure to mobile telephone base stations? An epidemiologic feasibility study comparing the Maschek dosimeter prototype and the Antennessa SP-090 system. Bioelectromagnetics 27(1):77-81,2006

24. Ronald J, Lemire, Joseph R: Neuroembryolgy. Neurosurgery Wilkins RH, Rengachary SS (eds) 2nd ed, 1996:346(3411-3444)

25. Robison JG, Pendleton AR, Monson KO, Murray BK, O'Neill $\mathrm{KL}$ : Decreased DNA repair rates and protection from heat induced apoptosis mediated by electromagnetic field exposure. Bioelectromagnetics 23(2):106-112,2002

26. Raskin CU: Apoptosis and cutaneous biology. J Am Acad Dermatol 36:885-896,1997

27. Sadler TW: Langman's Medikal Embriyoloji. Başaklar AC (çev), 7th ed, Ankara: Palme Yayıncılık, 1996:39-88

28. Sandström M, Wilen J, Oftedal G, Hansson Mild K: Mobile phone use and subjective symptoms. Comparison of symptoms experienced by users of analog and digital mobile phones. Occup Med 51:25-35,2001

29. Saikumar P, Dong Z, Mikhailov V, Denton M, Weinberg JM, Venkatachalam MA: Apoptosis: Definition, mechanisms, and relevance to disease. Am J Med 107: 489-506,1999

30. Sapunar D, Vilovic K, England M: Morphological diversty of dying cells during regression of the human tail. Annals of Anatomy 183: 217-22, 2001

31. Schoenwolf GC, Smith JL: Mechanism of neurolation. Traditional viewpoint and recent advances. Development 109: 243-270, 1990

32. Searle J, Kerr JFR, Bishop CJ: Necrosis and apoptosis: Distinct modes of cell death with fundamentally different significance. Pathol Ann 17: 229-259,1982

33. Yılmaz F, Dasdag S, Akdag MZ, Kılınc N: Whole-body exposure of radiation emitted from $900 \mathrm{MHz}$ mobile phones does not seem to affect the levels of anti-apoptotic bcl-2 protein electromagnetic. Biology and Medicine 27: 65-72,2008

34. Elektromanyetik dalgalar ve insan sağlığı sıkça sorulan sorular ve yanıtları. www.biltek.tubitak.gov.tr/sandik.gsm.pdf Tübitak-Bülten 2001 